ISSN 2078-6441. Вісник Львівського університету. Серія географічна. 2018. Випуск 52. С. 210-215.

Visnyk of the Lviv University. Series Geography. 2018. Issue 52. P. 210-215.

http:/ / dx.doi.org/10.30970/vgg.2018.52.10186

$901^{\wedge} 502+551 / 579$

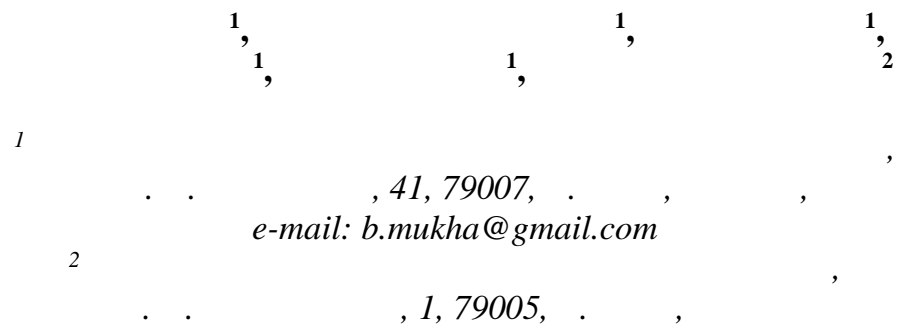

озглянуто проблему регіон льного, ч сто і глоб льного процесу ридиз ції, прояви якого з ост нні п'ять років ст ли вир зними й відчутними, особливо в сільському господ рстві. ведено ф кти обезводнення колись перезволоженої гумідної території, виявлено причини процесу риди3 ції, скл дено гр фік дин міки річних сум тмосферних оп дів з ост нні 48 років з трендом до збільшення, що д ло підст ву зробити висновок, що основні причини ридиз ції регіону поляг ють не у зменшенні кількості оп дів, зумовлені природно-історичними т водогоспод рськими чинник ми. о цього призвели тот льн осушув льн меліор ція 1960-1980-х років т інтенсифік ція сільського господ рств, т кож те, що кільк тисячоліть не було притоку флювіогляці льних вод. пропонов но з стосув ти методи сповільнення швидкого відведення вод поверхневого стоку, двосторонньої диференційов ної по геокомплекс х водної меліор ції т водоощ дні методи ведення господ рств в регіоні.

лючові слов : ридиз ція, осушув льн меліор ція, тмосферні оп ди, вип ровув ння, сповільнення швидкого скид ння поверхневих вод, водоощ дне господ рюв ння.

лоб льне потепління клім ту д вно обговорюють н всіх гром дських т урядових рівнях. одібно до потепління, ридиз ція щор з вир зніше ст є проблемою глоб льною і доповнюється політичними т комерційними ню нс ми, які в кожному регіоні м ють свої особливості [2].

ст тті . блія т . рохимчук ця проблем розгляд л ся із вк зув нням тенденцій розвитку проблеми і з рекоменд ціями щодо зменшення з гроз ії інтенсифік ції [1]. дн к минуло близько 30 років, і проблему можн верифікув ти т зб г тити новими д ними н турних моніторингових ст ціон рних вимірюв нь.

р вильним ув ж ємо визн чення термін , н ведене в пр ці: “ ридиз ція - це природний і одноч сно нтропогенний процес, що відбув ється н зн чних простор х емлі i поляг $€$ в прогресув нні зменшення зволоження території, незворотній зміні грунтового i рослинного покривів у бік ксерофітиз ції $\mathrm{i}$ зниженні біологічної продуктивності. екстрем льних умов х це може призвести до повного руйнув ння біосферного потенці лу, зн чного погіршення умов існув ння т господ рської діяльності людини" [1].

() ух ., ул чковський ., одич .,

ритул ., лик ., ернявський ., 2018 
ш посилен ув г до процесу ридиз ції з хідних регіонів кр їни зумовлен д ними спостережень 3 змін ми територій, де ми прожив ємо т н лізом результ тів інструмент льних вимірюв нь н озтоцькому л ндш фтно-геофізичному ст ціон рі, т кож результ т ми польових експедицій.

тверджуємо, що обводненість територій змінил ся к рдин льно. е видно 3 т кими ф кт ми: долин р. олокія 60 років тому бул низинним торфовищем 3 плям ми трясовини, що поросли високим очеретом, лише відв жні місцеві жителі могли пройти долину ріки впоперек і тільки у н йсухіший період літ . усло ріки було сильно ме ндров ним 3 петлями по кільк кілометрів і глибиною 2-4 м, м ло ширину 3-6 м. ерез 40 років після прокл дення шести осушув льних к н лів ${ }^{1}$ глибин води в к н л х т с мій олокії ${ }^{2}$ ст л недост тньою для пл в ння свійських гусей і вони ходять по дну, тоді як, до 1960-их років т м був р й для болотних пт хів.

долині п р лельної і менше перезволоженої р. олотня (промовист н зв ), що проляг є 310 км н північ, було т к мокро, що тр ву (осок ) н сіно скошув ли т к високо, щоб вон п д л н приземну стерню, висохле сіно скл д ли лише н ледь помітних підвищеннях, н стил х з верболозу і вивозили до господ рств ж по мерзлій тверді взимку. епер ці сінож ті перетворилися н м лопродуктивні п совищ для худоби, тр ктори їздять по колишніх сінож тях без ризику з грузнути.

долині р. олотні біля с. лівч ни був н йбільший у ьвівській обл. жур влинник ${ }^{3}$, 3 р ди збереження якого лісівники орг нізув ли 3 к зник “" олицький” і пост вили інформ ційний зн к. ісля цього, збир чі жур влин зорієнтов ні цим зн ком, т к ктивно їх ли н з готівлю ягід, що через три сезони жур влинник безповоротно витопт ли.

йвологішою місцевістю в околицях с. лівч ни тепер є еликі олини, де ще збереглися джерел в удк $\mathrm{x}$ лій i еликій. собливо зн ною і відзн ченою великим хрестом є с кр льн криничк, де вод ще не пересохл . од в ній злегк н пірн i перелив ється через пост влене бетонне кільце. вколо джерел мокро, ростуть високі очерети, люди приїждж ють сюди щоб н бр ти легенд рно см чної води.

олись були сильно обводнені урочищ упини, де росл купинист осок, в меж х c. лівч ни ще досі є дв великі і нез будов ні вигони - п совищ ( дж вк i лоске), де колись росли очерети, гніздились болотні пт хи. епер вони висохли, ст ли п совищ ми з викоп ними ям ми для збир ння води н водопій.

ст нні літ - 2015, 2016 і 2017 рр. - виявилися т кими посушливими, що попересих ли всі к н ли осушув льної меліор ції (н віть м гістр льні) т з вжди діяльні джерел і м лі річки. либоко опустився рівень води в колодязях, господ рі змушені були обл штовув ти глибокі свердловини з водними помп ми, щоб добув ти воду для н пув ння худоби т вл сного спожив ння. с д х оп д ли недозрілі фрукти, н добрий урож й з городів люди і не сподів лись. н шими спостереженнями, у 2017 р. ридиз ція території трив л , не було чути вечірніх “ж б'ячих концертів”, змінил ся звичн поведінк лелек, які колись ловили ж 6 у мокрих місцях, тепер для годівлі пт шенят ловлять свійських курч т і к ч т (див. рис. 1).

1 к густо прокл д ли к н ли, щоб скинути поверхневі води н території під будівництво вугільних ш хт.

2 ісцеві люди для озн чення мокрого і болотистого місця вжив ють слов “солокв" бо "солотв"

3 ур влин росте н г рно освітлених болот $\mathrm{x}$ і торфовищ $\mathrm{x}$. 
пис ні ф кти ридиз ції вв ж ємо дост тньо переконливими і т кими, що потребують інтелекту льного осмислення, спонук ють до господ рських корекцій і до випр влення помилок усім можливими доступними способ ми з р ди збереження вологи.
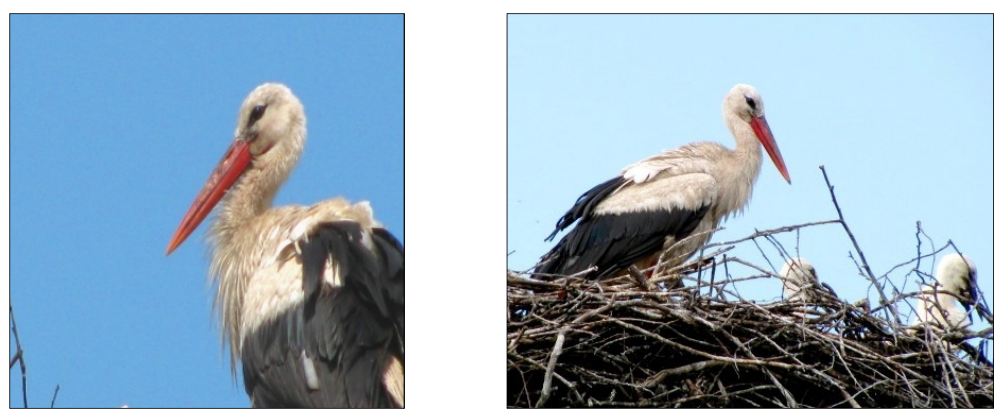

ис. 1. елек білий (бусько - Ciconia ciconia L)

Fig. 1. White stork (stork - Ciconia ciconia L)

голосимо, що ридиз ція сьогодні - це вже не регіон льн , глоб льн проблем . чені світу вже д вно пис ли про опустелення кр їн хелю, розширення посушливих зон, н ступ сухіших зон н вологі (степу н ліс). оду спожив ють промислово, площі лісів скорочують, площі ріллі розширюють, і це глоб льно, щоб з безпечити х рчув ння людств [1,2].

в ж ємо, що теперішній процес ридиз ції трив є вже довго, бо поч вся після стоку т лих льодовикових вод, яких було стільки, що вони не тільки перетік ли через внутрішні підвищення котловини річок ерхнього угу і тиру, й розв нт жув лись через річки ерещицю і ерет до ністр і орного моря. одосховищ, що з лишил сь у пониженнях долин рік, з безпечили формув ння глибоких (до 6м) торфовищ у 6 сейн х

хідного угу, тиру ерету т ністр . одішні флювіогляці льні води зробили н стільки потужну ерозійну т кумулятивну роботу, що тепер вигляд є сумнівними співвідношення розмірів тих ерозійних врізів (глибини т ширини) долин з тими потічк ми, які в них ще функціонують, продовжуючи відведення вод. рикл д ми можуть бути долини смового обужжя, лого олісся, ілогорщі, боліт, що живляться 3 джерел уздовж озточчя.

жливими чинник ми обводненості ьвівщини $є$ не тільки двективне перенесення вологи з оке ну, й оп ди, отрим ні від місцевого колообігу води. ок льні дощі вип д ють перев жно н ліси, луки і болот, бо т к їхня фізик (н д цими м сив ми повітря холодніше, швидше відбув ється процес конденс ції у хм р х) і цим потрібно корист ти. всьому вз ємопов'яз ному регіоні можн вносити корекції з умови пр вильної т узгодженої роботи [3, 4].

ег тивним прикл дом було проведення в р дянський ч с тот льної осушув льної меліор ції перезволожених земель. ершими н слідки п ртійного рішення н собі відчули білоруські вчені, які з говорили про “ср ботку торф ”, . еньков вид л пр цю 3 ж хливою н звою “ ск льпиров нн я емля” [4], довівши, що після осушення боліт торфовищ 3 зн ють розвіюв ння вітром і ч сто відкрив ється піщ не ложе, яке т кож переформовує вітер. е вже не тільки ридиз ція, й опустелення регіону. 
3 хідних обл стях кр їни, осушув льні меліор ції проводили необгрунтов но н територіях з короткопрофільними дерново-к рбон тними грунт ми, н схил х мергельних горбів і н піск х. е було злочинно стосовно природи і проти людей. кінцевому підсумку т кий розвиток суспільств - це шлях до с мознищення [4].

н лізуючи причини ридиз ції території, перш з все потрібно вр хув ти величини скл дових водного б л нсу рівнинних територій (прихід води від тмосферних оп дів т витр ти н вип ровув ння, фільтр цію вглиб т відтік води з території). ро н лізуємо результ ти довготрив лих ст ціон рних спостережень н озтоцькому л ндш фтногеофізичному ст ціон рі [3].

рис. 2 пок з но гр фік ходу сум оп дів з 1969 по 2017 рр., тобто з період, що охоплює ч с ктивного впров дження осушув льної меліор ції і 30 років після припинення ктивних осушув льних робіт. інія тренд кількості оп дів н озтоцькому л ндш фтно-геофізичному ст ціон рі з свідчує, що кількість оп дів не зменшується, т ки дещо збільшується. тже, причин ридиз ції-не у зменшенні кількості оп дів.

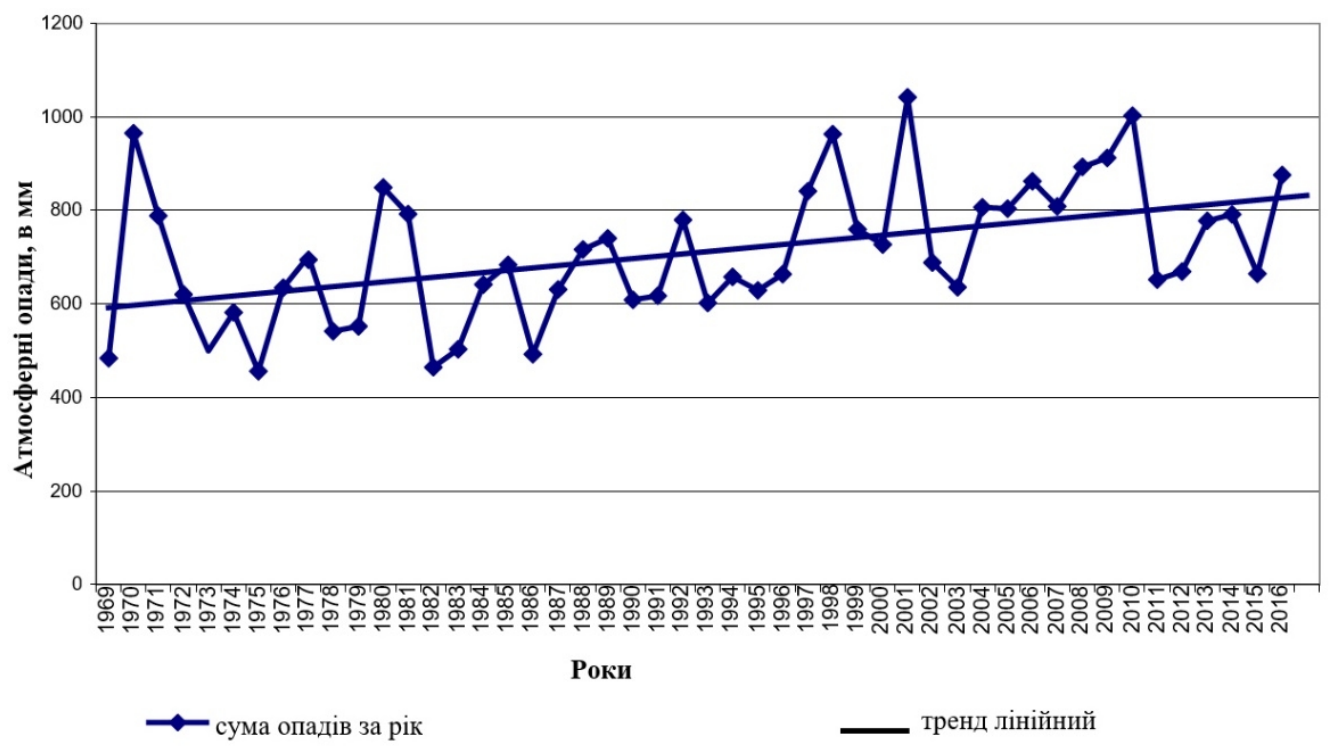

ис. 2. ин мік сум річних тмосферних оп дів н озтоцькому л ндш фтно-геофізичному ст ціон рі з 1969-2017 pp.

Fig. 2. Dynamics of the amount of annual precipitation at the Roztochia landscape-geographical station for 1969-2017

имірюв ння фізичного вип ровув ння т вип ровув ності з поверхні води, викон ні н цьому ж ст ціон рі доводять, що н йбільш кількість вологи вип ровується у серпні, липні і тр вні. зн чимо, що вип ровув ння більше з лежить від сухості повітря, ніж від його темпер тури [3]. оефіцієнт зволоження н озточчі, з н шими обчисленнями, ст новить приблизно 1,5, тобто 3 рік вип д $\epsilon$ в півтор $\mathrm{p} 3$ більше оп дів, ніж може вип рув тися, що х р ктерно для широколистих лісів. три літні місяці вип ровув ння перев ж є н д оп д ми, причому величезн кількість вологи (приблизно третин від кількості оп дів) кумулюється в грунті, поверхневого стоку м йже нем . 
к б чимо, водний $б$ л нс території з хідних обл стей кр їни близький до нуля і 3 лежить від флукту цій кожної з його скл дових, особливо від топоклім тичних умов, яким поступ ється н віть ст білізув льн роль літогенного чинник .

тже, ридиз ція хідного регіону кр їни є явищем суч сним, т кож причиннон слідковим бо зумовлен б г торічним відведенням вод рік ми ще від постгляці льного періоду, яке інтенсифікув лося спрямленими рік ми т к н л ми, прокл деними в ч си встрійського пр вління в личині т р дянської тот льної осушув льної меліор ції й розширення орних площ. дносторонній осушув льний дрен жз ост нні 1000 років викон в свою роботу, і н дмірн кількість води вже скинут . озширення орних площ н колись перезволожених землях, посилило фізичне вип ровув ння, тому тепер треб перейти до водоощ дного господ рюв ння в усьому регіоні, з стосовуючи н явні водорегулюв льні шлюзи, і створити моніторингову службу з н лежними регл ментув льними повнов женнями.

ротягом ост нніх років простежуються теплі і м лосніжні зими, що не сприяють поповненню грунтових вод. огляду н це пропонуємо з стосув ти методи сповільнення швидкого відведення вод поверхневого і грунтового стоків, ужити з ходи регулюв ння меліор тивної мережі, диференційов но по геокомплекс х відновити шлюзи, т кож водоощ дні методи ведення господ рств в регіоні.

ост нні дв роки ридиз ція виявил ся дуже вир зно. одібне відбув ється сьогодні в регіон х еликого олісся кр їни, де люди з р ди особистого короткоч сного зб г чення н видобутку бурштину знищують не вл сні, гром дські ліси, усю рослинність

т гумус, що н сотні й тисячі років можуть бути втр чені для н щ дків.

\section{C}

1. блій ., рохимчук . ридиз ція з хідного регіону кр їни // існик ьвів. унту. ер. геогр. 1994. ип. 19. . 26-31.

2. екин неукротимо н ступ ет пустыня. есч ные бури // еукротим я пл нет . рирод сходит с ум / ер. с нгл. зд. дом “ идерз. йджест”, 2008. . 88-95.

3. $y x$., $y л$ венко ., ельничук . ип ровув ння в кр їнському озточчі (з м тері л ми озтоцького л ндш фтно-геофізичного ст ціон ру) // існик ьвів. ун-ту. ep. геогр. 2014. ип. 48. . 117-124. DOI: http://dx.doi.org/10.30970/vgg.2014.48.1299

4. $y x$. еоретические основы и методические приемы л ндш фтних исследов ний для осушительных мелиор ций (н примере р внинной ч сти ьвовской обл сти: втореф. дисс. н соиск ние ученой степени к ндид т геогр. н ук по специ льности 11.00.01. физическ я геогр фия, геофизик и геохимия л ндш фтов. оскв , 1980.

\section{REFERENCES}

1. Shabliy, O., \& Trokhymchuk, S. (1994). Arydyzatsiya zakhidnoho rehionu Ukrayiny. Visnyk of the Lviv University. Series Geography, 19, 26-31 (in Ukrainian).

2. Na Pekin neukrotimo nastupaet pustynja. Peschanye buri (2008). Neukrotimaja planeta. Priroda shodit s uma. Perevod s anglijskogo. Izdatel'skij dom "Riderz Dajdzhest", 88-95. (in Russian).

3. Mukha, B., Bulavenko, I., \& Mel'nychuk, M. (2014). Evaporation in Ukrainian Roztochia (for materials belongs to the Rostochye landscape geophysical full-time department). 
Visnyk of the Lviv University. Series Geography, 48, 117-124. DOI: http://dx.doi.org/10.30970/vgg.2014.48.1299 (in Ukrainian).

4. Mukha, B. (1980). Teoreticheskie osnovy i metodicheskie priemy landshaftnih issledovanij dlja osushitel'nyh melioracij (na primere ravninnoj chasti L'vovskoj oblasti: Avtoreferat dissertacii na soiskanie uchenoj stepeni kandidata geograficheskih nauk po special'nosti 11.00.01. fizicheskaja geografija, geofizika i geohimija landshaftov. Moskva (in Russian).

m ття: н дійшл до ред кцї̈ 05.07.2017

доопр иьов н 25.10.2017

прийнят до друку 11.01.2018

\title{
THE ARIDITY OF PLAIN PART OF LVIV REGION AND WESTERN UKRAINE
}

\section{Bohdan Mukha ${ }^{1}$, Roman Kulachkovskyi ${ }^{1}$, Oksana Rodych ${ }^{1}$, Iryna Prytula ${ }^{1}$, Vasyl Chalyk ${ }^{1}$, Mykola Cherniavskyi ${ }^{2}$}

\author{
${ }^{1}$ Ivan Franko National University of Lviv, \\ P. Doroshenko St., 41, UA - 79007 Lviv, Ukraine, \\ e-mail:b.mukha@gmail.com, \\ ${ }^{2}$ Ukrainian National Foresty University, \\ O. Kobylianska St., 1, UA - 79005 Lviv, Ukraine
}

The purpose of this article is to analyze the problem and the reasons of regional and moreover global process of the aridity, which consequences have become more expressive and observed in the last five years, especially in agriculture. The work demonstrates obvious facts of the moist humid areas aridity. An important point of the article is consideration of the graph of the dynamics of the annual amounts of atmospheric precipitation for the last 48 years with the trend to increase. That fact led to the conclusion that the main problem of the aridity of the area was not the decrease in precipitation. The main reason was natural, historical and water management; the lack of millennial fluvial glacial water replenishment; the total drainage reclamation in 1960-1980 and agriculture intensification.

It was proposed to apply the methods of slowing the rapid removal of water from surface runoff; bilateral differentiated on geo complex water reclamation methods and water thrift methods of managing in the vast region.

Key words: the aridity, drainage reclamation, atmospheric precipitation, evaporation, slowing the rapid removal of water from surface runoff, water thrift managing. 